\title{
A POESIA DE LIBERTO CRUZ: ARTE E COMUNICAÇÃo
}

\author{
Carlos NOGUEIRA \\ Universidade de Vigo
}

\begin{abstract}
In this article we try to show how, in the work of the Portuguese writer Liberto Cruz, a compromise is established between the poem as a text free of any ideological imposition, and the poem as a social and political action; between the internal and personal experience of the author, and his commitment to the history of the country; between the self-sufficiency of the poem, and its links to the larger world; between the communication and elevation; between the work's expansion of image and semantics and the communication of feelings, emotions and ideas; and between the textual "I" and the biographical "I".

Resumo: Neste artigo procuraremos mostrar como é que se estabelece na obra de Liberto Cruz um compromisso entre o poema enquanto texto livre de quaisquer imposições ideológicas e enquanto ação social e política, entre a experiência interior e pessoal e o comprometimento na história do país, entre a auto-suficiência do poema e a sua ligação ao mundo, entre a comunicação e a elevação, entre o alargamento imagético e semântico e a comunicação de sentimentos, emoções e ideias, entre o eu textual e o eu biográfico.
\end{abstract}

Keywords: Liberto Cruz; Portuguese poetry; ethics; aesthetics; XX-XXI centuries.

Palavras-chave: Liberto Cruz; poesia portuguesa; ética; estética; séculos XX e XXI.

O livro de Liberto Cruz (Sintra, 1935) Poesia Reunida (1956 - 2011), publicado em 2012, é o corolário de um itinerário poético longo que começou em $1956 \mathrm{com}$ Momento, quando o poeta tinha apenas vinte e um anos. Seguiram-se, ainda na década de 50, A Tua Palavra (1958) e Névoa ou Sintaxe (1959). Na década de 60 saiu apenas Itinerário (1962), e nos anos 70 surgiram duas coletâneas, Gramática Histórica (1971), sob o pseudónimo de Álvaro Neto, e Distância (1976). Na década de 80 Liberto Cruz publicou Ciclo (1982) e Jornal de Campanha (1986), que recebeu o Prémio Cidade de Lisboa, na de 90 apresentou Caderno de Encargos (1994) e em 2000 o volume Sequências. Em 2007 o poeta deu a conhecer uma edição revista e aumentada de Gramática Histórica e, em 2012, na obra Poesia Reunida (1956 - 2011), incluiu um inédito, Três Poemas.

Com esta coletânea, que reúne onze livros, o público em geral e a crítica especializada passam a dispor de uma fonte imprescindível para a leitura e o estudo da produção de um poeta que tem feito o seu percurso com discrição. Ruy Belo recenseou Itinerário, Benedito Nunes, João Rui de Sousa, Maria Aliete Galhoz e Daniel Lacerda recensearam quatro livros de Liberto Cruz na Colóquio/Letras, Óscar Lopes dedicou-lhe quatro linhas na História da Literatura Portuguesa (s.d.), Haroldo de Campos, João Fernandes, Fernando J. B. Martinho e Eugénio Lisboa prefaciaram quatro livros do poeta, no Dicionário de Literatura Portuguesa (1996), organizado e dirigido por Âlvaro Manuel Machado, e no vol. 1 da Biblos - Enciclopédia Verbo das Literaturas de Língua Portuguesa há verbetes dedicados ao autor, Fernando Guimarães referiu-se aos livros Momento, A Tua Palavra e, em especial, Itinerário, numa secção de A Poesia Portuguesa Contemporânea e o Fim da Modernidade (1989), dedicada a Albano Martins, Cristovam Pavia, Helder Macedo e Liberto Cruz, e comentou, no JL - Jornal de 
Letras, Artes e Ideias, o volume Poesia Reunida (1956 - 2011, e Carlos Nogueira dedicou um subcapítulo do ensaio A Sátira na Poesia Portuguesa (2011) ao livro Gramática Histórica.

Poderíamos talvez juntar outras referências bibliográficas a esta enumeração, mas não chegaríamos a uma conclusão diferente desta: não há senão visões muito pontuais e pouco abrangentes sobre Liberto Cruz, cuja poesia aparece representada na Antologia da Novíssima Poesia Portuguesa (1. ${ }^{a}$ ed., 1959; 2. ${ }^{a}$ ed., 1961; 3. ${ }^{a}$ ed. revista e aumentada, 1971) de Maria Alberta Menéres e E. M. de Melo e Castro, mas não surge nas mais de 2000 páginas dos Poemas Portugueses - Antologia da Poesia Portuguesa do Século XIII ao Séc. XXI (2009), de Jorge Reis-Sá e Rui Lage, que selecionaram 267 poetas e um número muito variável de poemas de cada um.

Ao incluírem poemas de Liberto Cruz na Antologia da Novíssima Poesia Portuguesa, Maria Alberta Menéres e E. M. de Melo e Castro reconheciam o lugar que o autor de Momento ocupava na renovação da poesia portuguesa. Revelado na segunda metade da década de 50, o poeta participou de um "tempo de transição" (Guimarães 70) e de renovação em que o poema se assume antes de mais como linguagem, imaginação, sentimento e conhecimento do mundo, mas não recusa uma atitude crítica e de denúncia da repressão que se vivia em Portugal. Herdeiro dos princípios éticos e literários de revistas como Cadernos de Poesia (1940-42, 1951, 1952-53) e Árvore. Folhas de Poesia (1951-53), e de poetas como Tomaz Kim (1915-1967), Ruy Cinatti (1915-1986) e Jorge de Sena (1919-1978), Liberto Cruz concilia uma consciência muito aguda da linguagem com uma consciência também muito sensível da dignidade humana.

De Momento, o primeiro livro do poeta, não podemos dizer que seja apenas o preâmbulo de uma obra que dois e três anos depois, com A Tua Palavra e Névoa ou Sintaxe, estaria já bem afirmada, como o comprovaria, logo em 1962, Itinerário. Momento evidencia já, para utilizarmos o juízo que Fernando Guimarães aplica às primeiras obras de Albano Martins, Cristovam Pavia, Helder Macedo e Liberto Cruz, o "amadurecimento que não é muito vulgar nos primeiros livros de um autor" (65). "Momento", o primeiro dos vinte e sete poemas desta obra, antecipa claramente o tom da escrita deste autor, que já nesta fase conjuga confessionalismo e discrição, serenidade e inquietação, poeticidade e comunicação. $\mathrm{Na}$ assertividade e no despojamento dos versos iniciais do poema encontramos as características mais fortes da poesia de Liberto Cruz, que evoca e questiona o significado vivencial e espiritual dos momentos que passam, e ao mesmo tempo reconhece cinicamente a inevitabilidade de uma vida previsível e sem momentos sublimes:

\footnotetext{
Há sempre na vida

Um momento que é belo.

Mas tem de ser breve,

Leve,

Ser apenas um momento.

Dos toscos calhaus

Que o pinho cobre na serrania,

Há apenas um momento/
} 
- o brotar da água -

Em que a água lava,

Purifica.

Depois é o banhar da rotina,

O seguir sem pressas

O caminho que se adivinha. (19)

O poema oscila entre a afirmação da intensidade que a vida oferece e a constatação do desencanto que ela, em grande parte, é. Nesta composição aberta ao desejo mas consciente das limitações que a vida impõe, atualiza-se, de maneira não ostensiva, a relação entre poesia e pedagogia. $\mathrm{O}$ poema, que recupera $\mathrm{o}$ preceito clássico do deleite e utilidade, diz o que é a vida e, de certo modo, ensina a viver. Esta dimensão intensifica-se no final disfórico e desenganado, em que o sujeito que pensa se fixa mais na percepção da vocação do humano para o "ódio", o "rancor" e a "dor": "E que fazer, pensar, sonhar/ Se um dia o momento não chegar?/ Talvez nem sempre haja na vida/ Um momento que seja belo./ Ou talvez nos reste a dor,/ De também haver um momento para o ódio, para o rancor" (20).

Decantado mas muito sugestivo no conteúdo, é um texto que se vale dos mecanismos da lógica e da força das imagens da natureza. Lógica que se baseia quer na analogia entre a vida humana e a natureza, quer em imagens que, sem distorções retóricas nem obscuridades, são tão literais quanto, pela clareza e leveza dos versos, poéticas. No funcionamento desta poética não é menos importante o elemento prosódico, que também se vê nos primeiros versos de "Momento". O poema convida o leitor a partilhar uma experiência que tem tanto de intimidade pessoal como de universal. Neste estabelecimento imediato de cumplicidades entram não só as ideias e as imagens fortes mas também a eufonia criada pelas rimas em /e/, pela contiguidade de "breve", em final de verso, e "leve", em início de verso, e pela repetição da palavra-chave "momento", que, ao fechar a unidade sintática e semântica constituída pelos cinco primeiros versos, gera um "momento" musical que solicita a leitura e a audição dos outros versos.

Neste primeiro livro de poemas de Liberto Cruz, é já evidente como a imagem enquanto procedimento do discurso não está ao serviço da poesia que se rege quase unicamente pelo formalismo. A imagem não é, nesta obra, um processo de representação que visa a indecidibilidade e o esteticismo absolutos. Ela evoca primeiro um real empírico, descrito objetivamente, e só no contexto do poema é que cria ilusões referenciais que têm tanto de mundo concreto como de mundo projetado e simbólico; é uma imagem que se caracteriza pelo equilíbrio entre a mimese e a força de modelização do real evocado. Nos versos que transcrevemos há exemplos muito significativos que provam esta leitura, mas vejamos ainda este exemplo do "Poema para ser continuado": "Pior, pior do que tudo isso/ É ter na frente a estrada larga/ E não poder caminhar" (32). Trata-se de um caso de «imagem expansiva, que é aquela na qual cada um dos termos abre largo horizonte à imaginação e modifica fortemente o outro: é na metáfora expansiva que mais abundantemente ocorrem a "interação" e a "interpenetração" » (Wellek, René, and Warren 251).

Liberto Cruz usa a imagem para ligar o poema ao mundo, aos sentidos e ao pensamento do leitor, que se vê perante um objeto de linguagem rigorosamente 
construído a partir da consubstanciação entre a complexidade do mundo interior e o visualismo de referência empírica, entre cenários concretos e os conceitos que neles se expressam. Daí a afirmação de Fernando Guimarães de que "a imagem, quando surge nos seus poemas, não se isola numa construção que insista na suspensão ou elipse" ("Entre a Palavra" 16), ao contrário do que era mais comum na poesia de meados da década de 50 e na que se desenvolveu a partir da Poesia 61. A imagem de Liberto Cruz é representação de um objeto, de um momento, de um sentimento; mas também é um modo de o eu se situar perante o mundo e o mundo do pensamento, e a partir daí, como defende Jean-Paul Sartre, impor a sua consciência dinâmica e intencional no plano da ação individual e social (1940).

Em Liberto Cruz, imagem, metáfora e símbolo dialogam estreitamente. O poeta usa estas figuras para construir imagens e propor conceitos e reflexões sobre o lugar do eu e do ser humano português (e não só) no espaço e no tempo históricos e universais. Percebe-se que esta poesia tem referentes concretos, mas nem por isso perde em universalidade. Há um modo simbólico que se realiza pela conjugação entre os sentidos literais de uma expressão verbal e os sentidos indiretos que ela suscita. "Mar" (58), "dedos" (58), "saibro" (58), "sangue" (140), "terra" (140), "rios" (140): eis alguns dos símbolos que o texto apresenta mediante a sua inserção em séries de imagens. Mais atento às incidências imagéticas ou sensível tanto à realização das imagens como à experiência simbólica, o leitor é desafiado a envolver-se na interpretação e na construção de sentimentos estéticos e significados. Na primeira parte de Itinerário, intitulada "A Exata Viagem", lê-se: "Onde houver um espaço/ As suas mãos hábeis e livres/ Hão-de semear a semente do sono,/ $\mathrm{E}$ sacos cheios de trigo e lágrimas/ Hão-de habitar intangíveis/ Na frescura dos rios/ E no êxtase dos corpos" (140).

A construção do poema de Liberto Cruz não prescinde da instauração simbólica de um universo em que o eu e o ser humano encontrariam o seu espaço de libertação e criação. Imagem, metáfora e símbolo convergem no estabelecimento de um universo poético que põe em sintonia experiências coletivas e experiências individuais, o corpo e o espírito, o telúrico e o espiritual. No "Poema contra a cidade", de Névoa ou Sintaxe, a negatividade do espaço é acentuada pela função simbólica de imagens e metáforas: "Aqui na cidade nossos dedos não acabam gestos/ $\mathrm{E}$ a incauta presença nos suga/ O esforçado mel de todos os dias.// São inúteis os rios de resina,/ Todas as amoras maduras/ Que pisámos, bravos,/ No intervalo das estações.// As primeiras chuvas são apenas/ Primeiras chuvas/ E as crianças brincando são apenas/ Crianças brincando" (113).

"Dedos", "mel", "rios", "amores", "primeiras chuvas" ou "crianças" não são apenas metáforas nem só imagens. Constituem um imaginário simbólico que é o modo de o poeta expressar em linguagem poética uma realidade existente e uma realidade desejada; dizem o real e ao mesmo tempo significam uma "realidade transcendente" (Eliade 1997) que ultrapassa o tempo e o espaço físicos em busca de realização integral. Para além dos significados específicos que o título encerra, "Poema contra a cidade" convida o leitor a deixar-se envolver pela visão simbólica da realidade como forma de contrariar a mediocridade e a insipidez da realidade comum. Isto reforça o que dizíamos sobre a dimensão pedagógica da poesia de 
Liberto Cruz, que apela tanto aos sentidos e às emoções como à inteligência, à contemplação como à reflexão e à problematização.

A realidade figurada nesta poesia é a de um mundo natural (seres e substâncias dos reinos animal, vegetal e mineral) em articulação com o mundo do humano. É no universo telúrico que este eu vive e se pensa, sofre e projeta imagens de recriação de si e do universo; é na "terra", no "saibro", no "rio", nas "fontes", no "húmus" e nas "nuvens" que ele encontra o visível e o inefável. Mas estes mundos do telúrico de pouco valem perante o imobilismo do humano (a que não custa associar quer o contexto político-social de Portugal, que na década de 50 vivia os anos mais férreos do regime imposto por Salazar, quer o contexto mundial, num tempo que era de Guerra Fria):

\author{
Se procuro uma forma \\ Para os meus dias \\ É porque sei que a terra \\ Nos devolve, \\ Como quem oferece uma rosa \\ Ou acaricia um filho \\ Todas as formas que não conseguimos \\ E palpitam inolvidáveis \\ No barro e na água \\ Que nos cercam. \\ Mas nem sempre bastam \\ As tílias e o trigo, \\ Nem este sangue certíssimo, \\ De estevas e acácias, \\ Nem o mar que adivinhamos \\ Entre os pés descalços \\ E um barco velho \\ Onde bêbados pescadores \\ Dormem o sonho \\ Que o sal lhes não consente. \\ Que importa o mar \\ Se nossas mãos estão intactas \\ E nunca ferimos os dedos \\ Lavando o convés \\ Nem tão pouco vomitamos? (126-127)
}

A solidão e o pessimismo do sujeito destes poemas, em que se sucedem metáforas, imagens e símbolos muito ricos nos aspectos cromático, plástico e sonoro, alternam com a exaltação do mundo natural e a pulsão da viagem: "Eis que, de repente,/ Um barco/ E, às vezes, um pássaro/ Nos dá o sinal/ Que intimamente sabemos" (122). Esta vocação para a viagem e esta coincidência entre o humano e o natural veem-se numa estrofe como esta, da primeira parte ("O Rio") de Itinerário: "Um rio nos habita/ Desde o mais remoto barro/ E em piroga o corpo nos transforma/ E nos lança no húmido campo" (123). Uma vocação e uma coincidência que são metamorfose, plenitude e mistério: "Que desassombrada brisa/ Ou ígnea força/ Nos suportam,/ Não sei./ Todavia um fluido nos percorre o corpo/ E se instala/ Em todos os membros" (123-124). 
A opção não formalista de Liberto Cruz não o impede, contudo, também no seu primeiro livro, de construir imagens que exploram uma estética mais próxima da que se desenvolvia na transição dos anos 50 para os 60. "Poema", cujo título anuncia um texto que fala de poesia através da linguagem da poesia, é disso um bom exemplo: "Súbito, o gume veio/ Até nós e cortou cerce/ Os dedos da esperança./ E todavia,/ A música do sangue/ É ainda um ritmo de certeza" (35). Este texto, bem como o outro "Poema" que o antecede no livro Momento, também nos diz que o poeta não permaneceu indiferente ao dinamismo da imagética surrealizante, que é um meio de ele alcançar a libertação do espírito e da linguagem: "Seria fácil/ Estender o manto negro da distância/ E fumar o cachimbo do silêncio,/ Se os remendos do manto/ Fossem caminhos cegos/ E as cinzas do cachimbo/ Vulcões extintos há muito" (34). Estes enunciados não incorrem na obscuridade ou na arbitrariedade surrealistas; incluem preocupações sociais e existenciais que os ligam ao mundo físico e histórico.

$\mathrm{O}$ amor, tanto o mais espiritual como o mais erótico e carnal, é o tema dominante dos quase trinta poemas de Momento. "Concupiscência", talvez a composição mais sugestiva do conjunto de poemas de temática amorosa e eróticosexual, inscreve-se, apesar da sua brevidade, no que de mais inovador se fazia na poesia portuguesa: "Antes o sol rubro da ilusão/ E os beijos que se compram,/ Que o teu corpo virginal/ Em que não arde o desejo" (42). Reconhece-se a centralidade do corpo e do ato sexual, e denuncia-se a hipocrisia individual e coletiva. Nestes poemas, que são sobretudo de perda e de entrega não correspondida, há lugar para o equacionamento dos significados e do valor do amor e da sexualidade. Nos apenas cinco versos de "Dúvida" afirma-se, apesar do uso do conjuntivo, a legitimidade do "corpo sensual" que se "entrega" espontaneamente: "Talvez na entrega espontânea/ Dum corpo sensual,/ Haja mais luz, mais verdade,/ Que na renúncia fatal,/ Dum amor violentado" (48). E nos sete versos de "Loucura" declara-se a diferença entre "amor" e sexualidade: "E vivemos perdidos,/ Suspensos daquele beijo,/ Daquele ardor./ Esquecidos/ De que uma coisa/ É o prazer dos corpos/ E outra é o amor" (49).

Não falta neste livro inaugural a revolta e a insurreição, que se acentuarão muito fortemente noutras obras, contra as limitações sociais e individuais que afastam o ser humano da sua condição de ser livre e libertador. Referimo-nos ao poema "Cobardia", que é, como "Momento", assertivo e nítido nas imagens que comunicam a ideia enunciada no título, e veemente na acusação irónica, de que o eu não se exclui: "As portas estão abertas,/ Autenticamente abertas,/ Mas nós continuamos/ No pó ardente,/ Na lama seca,/ Que nos greta os pés./ E seria tão fácil,/ Tão humano,/ Escorrer a prisão dos dedos/ E mergulhar nas águas da aventura./ Ah! Mas isso era tomar uma atitude" (23).

É igualmente em Momento que Liberto Cruz estabelece o essencial do seu fazer poético no plano estrutural e sintático. Essencialmente breve na dimensão estrófica e na medida dos versos, esta obra inclui alguns poemas relativamente longos, que todavia nunca optam pelo discursivismo. Momento não contém poemas tão extensos como as A Tua Palavra, Névoa ou Sintaxe e Itinerário, mas há composições que os anunciam. Também a extrema brevidade do verso que háde caracterizar sobretudo o livro Ciclo aparece já neste primeiro trabalho, no 
poema "Desespero", cujos versos, que têm apenas uma ou duas palavras, se encadeiam numa continuidade frásica que exige uma leitura atenta aos nexos sintáticos e semânticos: "Mas só/ A lua/ Que brilha/ À noite/ No mar,/ É entre/ Milhares/ De amantes/ O único/ Que há-de/ Voltar" (47).

O segundo livro de Liberto Cruz, A Tua Palavra, publicado apenas dois anos depois de Momento, marca já uma nova fase na obra do autor. A opção pelo poema longo, organizado em estrofes não muito extensas, dá ao poeta mais espaço para a construção de uma poética que alia de modo mais consistente e apelativo a relação entre linguagem, subjectividade e conhecimento do mundo. Dividida em duas partes, a composição que constitui este volume desenvolve o compromisso entre a atenção conferida à palavra e a vertente testemunhal. Crítico, desiludido, porque "O tempo é de movimento,/ E a tua palavra não habita/ Em horizontes nómadas,/ Nem remota uma ave se desloca/ Ou imenso um rio nos inunda" (60), o sujeito poético expõe uma experiência religiosa estritamente individual marcada pela emoção e pela vigilância cognitiva.

Do espaço físico que o poema começa por evocar através da imagem do segundo verso, parte-se para um espaço reflexivo que dizemos "religioso" porque há algumas referências que vêm da tradição bíblica, não porque, como dizíamos, o texto identifique o interlocutor (convocado continuamente através dos deíticos de segunda pessoa): "Se o teu sangue já foi esquecido/ E os corpos já nada sabem/ De teus passos serenos?" (57); "E depois o que sabem os dedos,/ Da multiplicação do teu ser/ Flagrantemente distribuído/ Em cestos de água e peixes?" (58). O poema exibe, num envolvimento descritivo e narrativo, as misérias e os vícios humanos, o empobrecimento da vida, o artificialismo e o mal, o afastamento em relação à natureza e à natureza divina: "Aqui,/ Quando barcos sobem fluidos/ E espingardas se espalham pela terra,/ Quem poderá lembrar-se/ Da tua bandeira,/ Do teu incalculável pão,/ Da isenta forma dos teus dedos,/ Da compreensão justa dos teus olhos?" (56-57).

Ainda assim, num poema atravessado de melancolia e disforia, o final, que retoma o início diversas vezes convocado noutros momentos, é de esperança: "Aqui,/ Entre onda e pedra, vento e fogo/ Já não há lugar para a tua palavra.// E entre onda e pedra, vento e fogo/ Esperamos que a madrugada/ $\mathrm{Na}$ sua mais próxima palavra/ Um rosto novo nos cante" (61). Esta organização estrutural e estas imagens comprovam o que já dissemos sobre o mecanismo e a função da estrutura poemática e da imagem em Liberto Cruz: a preocupação com a arquitetura e com a matéria verbal do poema é válida em si mesma, mas também corresponde a um desejo de tornar a expressão comunicável e pragmática. Para isso muito contribuem as imagens desta poesia, que são, regra geral, ao mesmo tempo representações imediatas da realidade e percepções estéticas que combinam emoção (subjectividade) e intelectualização.

Névoa ou Sintaxe, o terceiro dos três livros que Liberto Cruz publica ainda na década de 50, é uma obra singular a vários níveis. O título parece sugerir a tensão que se estabelece entre o emocional e o trabalho poético, a abstração ou a impessoalidade e a linguagem rigorosa e transitiva.

Afirmámos acima que os primeiros livros de Liberto Cruz têm como grande universo de referência a produção dos anos 50 , de poetas que se organizaram à 
volta de revistas como os Cadernos de Poesia (em que também participaram Sophia de Mello Breyner Andresen, Eugénio de Andrade e António Ramos Rosa). Mas esta adesão a uma poesia escrita por autores nascidos cerca de vinte anos antes de Liberto Cruz não significa que a sua produção seja insensível a influências mais antigas. Aliás, o esteticismo desta poesia, quer venha mais ou menos diretamente dos simbolistas e modernistas, quer seja mais ou menos mediado pelos poetas da década de 50 a que nos referimos, não deixa de ser herdeiro das poéticas da Modernidade desencadeadas por Rimbaud, Mallarmé e Baudelaire.

"Poema maldito" é o poema deste livro em que mais imediatamente se percebe essa relação entre a memória literária e cultural e a voz individual de Liberto Cruz. Este texto, que à contenção e à discrição psicológica prefere a comunicação mais dramatizada e indiscreta, aproxima-se da poética da Presença. Colocando em epígrafe uma passagem do poeta brasileiro Jorge de Lima, que colaborou na revista Presença, o poeta expõe o drama religioso que o atormenta: "Ao vento, ao vento, e entre cânticos/ Te ergues, ó guerra, ó insensível guerra!// Te ergues, te ergues/ E tudo destróis e tudo começas" (74). Essa epígrafe é retomada na última estrofe, constituída apenas por três versos com muito de confessionalismo e emoção à José Régio e à Miguel Torga: "Senhor,/ Senhor, por que me ensinastes a perguntar?" (75). A aproximação entre aqueles poetas e Liberto Cruz estabelece-se ao nível da atitude e dos procedimentos de escrita, mas não no conteúdo. "Poema maldito", apesar de no final questionar crítica e comovidamente o "Senhor", que constitui o interlocutor de outros poemas de Liberto Cruz, não é um texto de oposição aos valores e aos rituais do cristianismo.

Em Itinerário, o único livro que Liberto Cruz publica na década de 60, o domínio do poeta sobre a linguagem e o seu poder encantatório e comunicativo está já plenamente constituído. A terceira e última secção de Itinerário, "A Exata Viagem", confirma o uso que Liberto Cruz faz quer da imagem, do símbolo e da metáfora quer da comparação. A frequência com que esta figura aparece neste poema não prejudica o poder evocativo do texto; diminui propositadamente, por momentos, a intensidade metafórica, mas não afeta a expressividade estilística e imagética nem a subtileza do pensamento: "Aqui um gesto limita carícias como vidro esmagado" (139); "Prodigiosos os insetos,/ Cujo vocabulário é tão reduzido e ondulado/ E sentem a morte/ Como os pássaros escuros e sem destino" (139).

$\mathrm{Na}$ terceira parte de Itinerário, e noutros livros de Liberto Cruz, o processo comparativo, que às vezes inclui símbolos universalmente reconhecidos e usados em diversas artes (como o "rio", que simboliza a passagem do tempo), tende a consubstanciar-se numa construção metafórica que se alarga numa imagem: "Virás lentamente como um rio antigo" (141). O destinatário deste poema, tal como os dois anteriores longo e dividido em várias estrofes de dimensão variável, é a "Primavera", que se contrapõe a um tempo e a um espaço asfixiantes, definidos nestes termos logo no primeiro verso: "Falo de um tempo incolor" (139).

A acumulação, a alternância e a sobreposição destas figuras produzem um efeito imagístico muito impressivo que convoca a sensibilidade e a inteligência do leitor. Na segunda estrofe, que é uma invocação (ou apóstrofe) da "Primavera", temos um bom exemplo deste procedimento, que implica sempre uma exploração 
dos limites semânticos das palavras: "Onde estás Primavera de vinho e loucura/ Que não nos restituis as acácias/ E os peixes das ervas pequenas e sadias" (139). Interpelada pelo eu, a "Primavera" é-nos apresentada enquanto imagem, no primeiro verso, e ponto de partida para imagens e símbolos telúricos ("acácias", peixes"), nos dois versos seguintes. Mas estes três versos são igualmente uma metáfora ou uma sequência de metáforas: "Primavera" metaforiza também o mundo humano justo e ideal a que o eu aspira.

Itinerário confirma a oscilação, típica desta poesia, entre melancolia ou abatimento e esperança. A segunda parte, "Dádiva", é um momento de pacificação na angústia do eu-poeta, que dirige o poema a um destinatário nomeado através de deíticos de segunda pessoa: "Nada te detém. És entre os abetos/ Como um cristal no tempo,/ E teus pés de terra e brisa/ Se fixam e soltam a cada beijo" (131). O destinatário da dedicatória que antecede o texto, "A minha mulher", não coincide com o objeto do poema. O termo masculino que aparece na segunda estrofe indica que não os podemos associar: "Inevitavelmente humano/ Te inscreves e apagas/ No ácido dos corpos,/ E vasto e restrito/ Os membros começas/ Os membros corróis" (131). Contudo, seja qual for o tu a quem o sujeito poético se dirige (o Amor, Deus, Cristo...), este texto equaciona mais uma vez a relação entre o estético e o ontológico, entre a palavra e a indagação dos mistérios do eu e do mundo: "Como a necessária chuva/ Vens extenso e livre/ Purificar-nos/ Este caminho/ Que desejamos sólido/ Mas se divide e esconde/ Entre as areias" (133).

Em Distância, publicado em 1976, a nomeação da realidade social e política intensifica-se, mas isso não implica um desinvestimento do trabalho poético, que é neste volume particularmente cuidado. A epígrafe, "De amor e de poesia e de ter Pátria aqui se trata", retirada da obra de Jorge de Sena Exorcismos, indicia essa relação, que não é imediatamente óbvia, entre o real e o poético. A primeira parte de Distância, livro dividido em sete sequências que valem ao mesmo tempo como poemas autónomos e como momentos de um todo, não inclui ainda as palavraschave "Pátria" (159), "exílio" (160) e "país" (180), que situam o leitor num universo que é de subjectividade muito íntima e de enquadramento político e social: "Selim de cruzados dedos,/ Imagem/ Derradeira/ Bichos abrindo devagar// O trajecto horizontal./ De maças renasce/ Vício renovado,/ A amada: lábios// E seios./ O álcool/ Dromedário, areia/ oscilando/ Noite já moribunda.// A seiva e a loucura/ De quem não morre jovem nem é deus" (151).

Uma passagem como "Quem de si foge/ No vil terreno/ A casa regressa,/ Um sismo escreve/ Na semente dos filhos" (153) ou um verso como "Ruptura de paisagem" (154) indiciam essa relação entre o histórico e o pessoal: a "distância", a que alude o título do livro, que separa o poeta do seu país e de si. Mas os termos que indicam a ligação do eu à realidade circunstancial e histórica, e expõem a sua experiência de perda, dor e alguma confiança num futuro mais positivo, surgem apenas noutras sequências do livro. É o caso das palavras "medo" (162), "pranto" (167), "estrangeira" (168), "solidão" (178), "saudade" (179) ou "esperança" (172): "A medo mastiga/ O ruído da casa,/ Íntimo/ Azulado retrato/ Que ainda absorve" (162); "Disperso/ Medo a máscara/ Vestem. Ombros pintam" (167); "Intranquila cinza/ Idêntica/ Em estrangeira/ Terra flutua" (168). 
Há, na poesia de Liberto Cruz, e neste livro em especial, a consciência de que o mais estético não é necessariamente o menos comunicativo e utilitário. Distância é um livro que envolve o leitor no processo de leitura, convocando-o quer pelo que nestes versos há de pesquisa da forma, de ambiguidades e subentendidos próprios da poesia pura, quer pelo que neles existe de sensibilidade moderna que não ignora o circunstancial e o histórico-político. O cuidado com os requintes formais não é maior do que a atenção concedida ao conteúdo e à mensagem, que não é exagerado qualificar de revolucionária.

Em Ciclo, o livro que Liberto Cruz publica depois de Distância, também existe esta contenção e este poder evocativo de cheiros, cores, imagens e lugares do passado e da infância: "Sinto lenta-/ mente a terra./ Ardendo. Bafo/ Regular de bois,// Ondulado fumo/ De trilhos, laba-/ reda suicida/ De pirilampos.// Terra vasta/ Da infância,/ Neblina fácil/ Trespassando/ A habitação/ De coisas. Ali" (183).

Constituído por dez poemas que também podem ser lidos como uma única composição, este volume compreende exclusivamente sonetos de métrica irregular, que já aparecem, embora ao lado de outros poemas, em Distância. Nestes versos de uma, três ou, raramente, quatro palavras, há unidades sintáticas de diverso tipo, desde o verso que é em si mesmo uma frase, até à continuidade discursiva que comporta mais ou menos versos: "Um nome baloiça./ O rosto grava,/ Cilício de sílabas,/ O silêncio// Mercenário.// Ouropel antigo,/ Vertigem/ Plani-// ficada em corpo/ De mulher. Vago/ Tecido// De carícias,/ Enredados/ Dedos (185).

Uma construção assim tensa, que pela primeira vez em Liberto Cruz até recorre ao encavalgamento, pede ao leitor um trabalho constante de associações, de atribuição de sentidos e de organização temporal. Mais uma vez, o poema tende a surgir da intersecção de tempos e espaços distintos, do passado e dos lugares da infância: "O retrato dos pais/ Se desenha,/ Face aos dias/ macia// Chave/ De sonhos repe-/ tidos./ A flora a fauna,// O rio queimando/ A ordem o medo./ Há ainda a lisura// De um beijo, ronda/ Adolescente,/ Leito de feno" (184). A brevidade destes versos, que se assemelham aos haïku no minimalismo e na sugestividade, não é mera condensação formal e cristalização de sentidos; é, na linha das poéticas da modernidade que remontam a poetas como Mallarmé, Valéry e Rimbaud, um dizer que parte da fragmentação e do instante para a intensificação de sensações e imagens e para a descoberta de significados.

É em Sequências, escrito em Lisboa entre 1989 e 1997 (376), que a vocação de Liberto Cruz para o minimalismo poético e para a fixação do instante se aproxima mais da forma e do conteúdo dos haïku. Saídos do mundo que o poeta vê e dispostos em "sequências", estes poemas querem captar a essencialidade do ritmo natural e cósmico em imagens transparentes e puras: "Na primavera/ as acácias/ incendeiam/ a lagoa" (342); "Após as abelhas/ os melros./ Disciplinados/ bebem/ a água do regato" (376).

Mas, ao contrário dos haïku, muitos destes poemas não nascem apenas da necessidade de representar uma sensação mental e física associada à natureza; o observador não se afasta do que observa, reflete sobre si e sobre a vida, questiona: "As águas em sossego./ Um barco à vela./ Uma gaivota longe.// A tua ausência 
dói" (341); "Louvor ou pranto/ é das aves/ o canto matinal?" (345). Existe economia de meios nestes haïku de Liberto Cruz, mas nem sempre se verifica o apagamento do eu, que por vezes escreve em primeira pessoa ou se dirige a um tu: “Águas do mar:/ que olhos te seguem?/ que segredos segredas?" (331). É de um eu na natureza e no mundo humano que se trata, não de um sujeito que observa com neutralidade: "Espero a amada./ As estrelítzias/ fazem-me companhia" (330). Um eu, ainda assim, que, como faz Bashô nos seus haïku, perscruta a intimidade das coisas e quer transmitir a totalidade que coincide com a sua simplicidade, para poder experimentar a realidade de modo direto (sem se perder em palavras e conceitos): "Um espantalho./ Um melro/ pousa-lhe no ombro.// O homem de palha/ parece sorrir" (340).

Em Jornal de Campanha, a imaginação criadora de Liberto Cruz continua sensível à disciplina da forma e ao compromisso ético com o tempo histórico. Este livro contém uma intenção clara de refletir e conduzir à reflexão que se apoia num testemunho confessadamente autobiográfico. O universo de referência é a guerra colonial, em que o poeta participou entre 1962 e 1964: "Cumpro ordens como quem rouba um pão" (202); "E todos os dias se morre na terra dos outros" (203). Para orientar a leitura e suscitar no leitor o prazer do reconhecimento e da intimidade de uma subjectividade vigilante, o autor, a abrir o livro, assinala: "Este diário foi escrito em Buela, Luanda e Sintra, entre Maio de 1962 e Janeiro de 1965" (197). É um diário poético, atento ao fluir do quotidiano na sua tragicidade mas também nos seus ridículos e baixezas humanas, em que convergem emoções, sensações e inteligência, e em que não há simples habilidades de construção e efeitos de retórica. Cada poema, muito simples e simultaneamente muito cuidado prosódica e semanticamente, surge do diálogo entre o emotivo e o intelectual.

A ironia, ora melancólica ora amarga, constituída a partir de imagens do real concreto, é uma constante neste livro, que em vários poemas se quer abertamente provocatório: «Pobre Generala! Todos os meses tem de ir a Lisboa/ "arranjar o cabelo"./ E os aviões militares são tão lentos » (228); "O Alferes é inteligente. O capitão é mais inteligente./ O Tenente-Coronel é ainda mais inteligente./ E quando o Alferes é imbecil?" (238). Em textos curtos, epigramáticos, Liberto Cruz desenvolve uma das dimensões mais originais da sua personalidade humana e artística: a articulação entre crítica irónica e sarcástica, que há-de ser retomada no livro Gramática Histórica, e desencanto, dor, perante o absurdo da guerra e o sofrimento que ela impõe a quem a vive. Inconformado, o poeta expõe o que viu, comenta uma matéria que é simultaneamente individual, política e social, e denuncia as mi(s)tificações, as contradições e as fragilidades de um país que dia a dia destruía o seu futuro e o futuro das suas colónias ultramarinas.

Jornal de Campanha confirma a ideia de que a poesia de Liberto Cruz não quer apenas testemunhar; quer também intervir no mundo através da linguagem poética, e por isso constrói-se enquanto pensamento e ação. O leitor encontra em cada poema pequenas histórias ou casos e comentários lapidares que associam ironia, sátira e humor, num ambiente de guerra de que o poeta é participante: "Com um serrote de cozinha, o médico cortou, há pouco,/ Um braço a um soldado.// A mão armada também salva" (204). A meditação existencial alterna e funde-se com o acontecimento mais trágico, comum e brutal. O que subjaz a estes 
versos, contidos mas intensos na crueza e na verdade das imagens, é a brutalidade e a desumanidade do homem que comanda e mata por ofício e daquele que é obrigado a matar: "Situação normal" disse o Alferes./ Reparei que um soldado tinha um cinto de orelhas » (236). Daí a distinção irónica e satírica entre oficiais e simples soldados, que, apesar do que os distingue em termos hierárquicos e de comportamento, são iguais perante o sofrimento e a morte que chega repentinamente: "Uma mina matou esta manhã o capitão./ A guerra não escolhe nem homens nem postos" (210).

Mas nem tudo é sátira e ironia ácidas neste livro, que nos fala da guerra ultramarina portuguesa e da classe dirigente, de Portugal e do Império (português e não só): "Quem sonha no país no alheio? Quem ama na terra alheia?" (204). O cepticismo que resulta da consciência de uma guerra inútil e injusta traduz-se também em versos que, não isentos de sentido crítico, se traduzem numa ironia mais melancólica do que panfletária: "Após um mês sem notícias chegou agora o correio./ Lembrei-me de Júlio Dinis" (214). Liberto Cruz constrói ainda versos cujo lirismo nostálgico e amoroso é igualmente um modo de resistência: "O rio. O teu retrato. Um pássaro no horizonte" (211). Poemas como "O trilho é água e vento./ De outrem ou nossa é a morte" (208), "Os homens têm raízes mas voam como corcéis" (208) ou "Confirmado pelo Vergílio Ferreira sei que/ "o existencialismo é um humanismo",/ E a existência da guerra? » (228) evidenciam a vertente ontológica e existencialista deste livro, que nasce da solidão meditativa e da experiência direta de um poeta que foi soldado e nos convida, através destes versos, a não esquecermos o valor da memória na construção de um mundo novo. A memória que é o território por excelência dos escritores, que no tempo da escrita destes versos estavam demasiado calados, como Liberto Cruz nota amargamente neste texto: "Onde estão os escritores do meu País,/ Ó António Nobre, que nada escrevem sobre esta guerra?" (231).

No livro Caderno de Encargos, o oitavo na produção de Liberto Cruz, o poeta questiona o seu destino, a sua errância física e psicológica de emigrante e estrangeirado, e questiona também o destino de Portugal e do Império. "Pátria" (298) é por isso uma das palavras-chave desta obra (e desta poesia), que, escrita "em Paris e Sintra entre 1984 e 1990" (257), reúne sessenta e seis sonetos em metro heptassilábico. Os dois versos de Alberto Caeiro que o autor coloca em epígrafe ("Ser poeta não é uma ambição minha/ é a minha maneira de estar sozinho") (257) antecipam o tom intimista e de recolhimento que o primeiro texto, subordinado ao tema do corpo (físico) e do envelhecimento do poeta, confirma: "Afinal que corpo é/ Este que sinto já não/ Sendo meu e todavia/ Me persegue e precede// E comigo sempre anda/ me vigia e censura?/ Que desertos ou montanhas/ O mudam ou o limitam?" (259).

No plano da forma, Caderno de Encargos introduz assim uma inovação nesta poesia, que, apesar de alguns versos relativamente longos como "São tochas acesas o que nossas mãos suportam" (58), prefere a segmentação da sintaxe e, consequentemente, do poema. O rigor desta micro(estilística) não diminui neste volume, cuja disciplina está bem patente na opção pelo soneto e pelo verso de sete sílabas. Sonetos que se apresentam, portanto, propositadamente em arte menor, sobretudo se pensarmos nas composições decassilábicas, com um esquema 
rimático fixo que não existe em Liberto Cruz, de Sá de Miranda ou Luís de Camões.

Estes sonetos não são clássicos na estrutura, mas são-no na sobriedade e na elegância do estilo, e na serenidade do registo, apesar da certeza do poeta de que a harmonia e a paz interiores são inatingíveis. Este é um livro que se constrói sob o signo da melancolia, da recordação e da meditação, da nostalgia do que passou ou não se viveu e do cepticismo em relação ao que há ainda que viver. Liberto Cruz aproxima-se do leitor, expõe-se autobiograficamente em poemas que podem ser lidos como momentos organizados de uma escrita diarística em verso: «Estação de Austerlitz:/ O "Sud-Expresso em linha./ São dezanove e quinze/ Duma tarde de Setembro.// Vejo um povo deportado/ Caminhando pelo cais./ Foi um ato voluntário de quem ama sua terra » (304).

Reaparecem neste livro os temas e os motivos das obras anteriores: a pátria e $o$ exílio, a evocação da infância e da juventude na terra natal, o amor e o erotismo, a vida e a morte, o dia a dia, a família, a meditação ontológica, a natureza, a guerra, a palavra poética. Todos estes elementos convergem no último soneto, em que mais uma vez surge o tema da viagem; viagem cronológica, viagens físicas, viagem (metafórica) pela vida. A pulsão ou a obrigatoriedade da viagem, que logo nos primeiros livros de Liberto Cruz aparece figurada nas metáforas e nos símbolos da "água", do "mar", do "rio", da "estrada" ou do "barco", como em "águas da aventura" (23) e "lançaremos ainda um grande barco" (27), é, neste poema que prescinde da vírgula, viagem da vida para a morte: "Agora viajo já/ A despedir-me da terra/ Onde eu vivi amei/ Tive filhos a mulher// De sempre companheira/ De toda a guerra à paz./ Agora viajo já/ Da terra misteriosa/ Para a terra do mistério./ É o fim ou o começo/ Da viagem? Que importa?" (324).

Há neste soneto uma consciência da irreversibilidade do tempo cujo tratamento se filia na "filosofia prática" (Coelho 39) dos estóicos e de poetas como Horácio ou Ricardo Reis. O reconhecimento de que a vida é efémera e breve e de que a morte é "Inevitável e certa" (265) leva o poeta a construir, não sem ironia e sátira (cósmica e social), máximas: "Disponíveis locatários/ A vida toda corremos/ Sem licença nem contrato/ E as bagagens deixamos// Às vezes na praça pública./ Somos a toda a hora/ Lobos de pele alheia" (281). Este eu não é moralista como os estóicos e os clássicos que defendem os seus princípios; constata a nossa tendência para a intranquilidade e o excesso, e propõe indiretamente a adoção de serenidade e autodomínio interior como remédio contra as paixões e o sofrimento: "Mas para quê tanta ânsia/ Tanta pressa de chegar/ Onde todos acabamos?" (281).

Mas, ao contrário dos estóicos e dos epicuristas, o poeta não se abstém dos sentimentos fortes e dos prazeres trazidos pelo amor, que é um dos grandes desígnios desta obra poética e da vida humana que aqui se comunica: "Uma só vida não chega/ Nem outra nem outra ainda/ Para dizer que te amo/ Meu amor meu só amor.// E quando a morte vier/ Inevitável e certa/ Que seja eu o primeiro/ A ficar no livro inscrito.// Que ali discreto seja" (265). Os tópicos da morte por amor e do amor absoluto simultaneamente físico e espiritual que nem a morte pode vencer, glosados na literatura portuguesa desde os cancioneiros medievais, têm neste soneto uma expressão que sintetiza plenamente toda essa tradição de um sentimento cuja sublimidade é dita, em eco camoniano, no último terceto: "E feliz 
por ter amado / A mulher por que morri// Vivendo. Nada mais quero./ Se de seu amor morri/ Morrendo volto a viver" (265).

Colaborador da revista Poesia Experimental (1964 e 1966), Liberto Cruz é o autor de uma das obras mais notáveis do experimentalismo português: Gramática Histórica (Funchal, 1971). Este livro, que, como nos lembra o autor na "Nota desounecessária dos autores" da edição de 2007, esgota numa semana, tem como objetivo desconstruir paródica e satiricamente a linguagem e a ideologia do regime salazarista. Quando a crítica oficial se apercebe do registo subversivo dos textos, já todos os exemplares estavam nas mãos de "atentos e desobedientes leitores" (10). Liberto Cruz dá ao seu apontamento introdutório um título irónico, "Nota desounecessária dos autores", porque na primeira edição ele oculta a sua identidade sob um pseudónimo: Álvaro Neto, que, em 1966, no segundo e último caderno da Poesia Experimental, aparece como autor de vários poemas.

Esta Gramática Histórica, produzida entre 1962 e 1966, "revisita", como escreve João Fernandes num dos prefácios que acompanham a segunda edição, "categorias e fórmulas de uma gramática tradicional, utilizando porém práticas da Poesia Visual e Experimental do século XX que revolucionaram a literatura e as artes visuais no contexto português e no contexto internacional" (12). O livro, organizado ironicamente em quatro partes, que correspondem às áreas fundamentais da linguística (Fonética, Morfologia, Sintaxe, Semântica), apoia-se nesse movimento de dissecação e reconstrução de Portugal e da sua gramática oficial.

Gramática Histórica é um livro que se assume como experimentação e jogo lúdico, como poética e conhecimento social e histórico. Liberto Cruz desmonta, recompõe e associa palavras, destaca e combina grafemas, cria uma arrojada sintaxe visual e significante: propõe uma nova gramática, um novo discurso, um novo pensamento. Cada texto, do mais breve, como as "Frases idiocráticas" ou os "Provérbios", ao mais longo, como as "Minutas de requerimentos, atas, ofícios e atestados", é um exercício de inteligência criativa, estética e ética: "É um grande prazer estar entre esta gente calma, paciente, ordeira, resignada, crente, esta gente bem portuguesa" (82); "Um verdadeiro português contenta-se com um quarto de pão e uma sardinha assada" (83); "Emigrar ou não emigrar/ eis a questão" (108); "É preciso trocar o certo pelo incerto" (109). A atividade lúdica, que E. M. de Melo e Castro valoriza como "parte vital do ato crítico desmitificador (sob a forma

\footnotetext{
1 "Tenho a honra de comunicar que,de acordo com as instruções recebidas de V.Excelência,tenho zelado sempre pela boa ordem na nossa Repartição estando constantemente atento às conversas que possam desvirtuar os bons costumes portugueses.Não me têm escapado igualmente as palavras menos respeitadoras e os grosseiros impropérios,certamente por influência estrangeira,susceptíveis tantas vezes de denegrir a moral e a paz que entre nós,graças a Deus e a bem da Nação,existe.Moral, nunca é de mais lembrá-lo,de que V.Exa. é um exemplo pelo aprumo,pelo patriotismo,pela modéstia,pela abnegação,pela crença na Santa Madre Igreja e ainda,permita-me que o diga por disso ser testemunha,pelo brio com que recebe e faz cumprir as ordens superiores da Pátria (...)".Nesta "Informação de serviço (incompleta)", dirigida ao "Exmo. Senhor Diretor" (103), que reproduz o tom e a forma de um relatório de acusação típico dos informadores do regime, não há espaçamento entre o sinal de pontuação e a palavra seguinte. Notamos este desvio tipográfico, que, como é óbvio, faz parte dos procedimentos irónicos e sarcásticos do texto, para que não se pense tratar-se de um erro nosso.
} 
de ironia) e, indo mais longe, como via de descoberta e criação" (207. Sublinhados no original), entra como força vital de transgressão, invenção e liberdade.

Três Poemas, o livro inédito que Liberto Cruz dá a conhecer neste volume, comprova o que dissemos sobre o rigor característico desta poesia, que se quer ao mesmo tempo palavra e comunicação, referencialidade. Significativamente dividida em três partes, "Construir", "Evocação" e "A Pedra o Corpo", esta obra mostra-nos que há um projecto poético que se vai concretizando na elaboração de cada poema, sujeito a um trabalho planeado que exige esforço, matéria verbal e vida (a do poeta e a de tudo o que ele observa e vivencia):

\author{
De papel e saibro \\ Se ergue o cabouco \\ Do verso. Vegetais \\ Pendem na argamassa. \\ Há indícios breves \\ Da colher raspando \\ A pedra o fio de prumo \\ Que se distende. \\ Na palma da mão \\ A aragem \\ Cicatriz \\ Que desbasta. \\ Devagar se move \\ A palavra \\ A areia necessária \\ Ao corpo do poema. \\ O martelo do vento \\ Alcanço. $\mathrm{O}$ vigor \\ Da sílaba \\ A nítida nervura \\ Da frase sopeso. \\ Sons e gestos. \\ Lentamente o cimento \\ Adere. Novas linhas. \\ Traços velhos copio. \\ Depois apago. E depois \\ Escrevo. (515-516)
}

"Escrito em Paris em 1978" e "Revisto em Lisboa em 1993" (532), "Construir", composto por sete partes, cada uma das quais constituída por estrofes de versos muito breves, é um poema de pensamento metapoético que nos coloca em diálogo com os outros livros do autor (excetuando-se, evidentemente, Gramática Histórica). Reconhece-se imediatamente uma unidade quer ao nível da estrutura do verso curto ou muito curto, que, como vimos, vem já de um poema de Momento, quer ao nível do léxico. Há vocábulos, como "saibro", "areia", "palavra", "pedra", "mão", "corpo" ou "vento", que se repetem e geram um efeito de coesão. 
Esta homogeneidade não diminui a capacidade evocativa e comunicativa da poesia de Liberto Cruz. A reiteração lexical sugere a existência de um macrotexto, mas não interrompe a riqueza das imagens, das metáforas e dos símbolos, nem o intimismo e a ligação ao real. Na passagem que transcrevemos no parágrafo anterior, "A palavra" é "A areia necessária/ Ao corpo do poema" e "vento" surge na imagem "O martelo do vento" (515). "Palavra", "areia", "corpo", "poema" e "vento" aparecem-nos assim numa situação de unidade e continuidade mas também de diversidade; de repetição e simultaneamente diversificação de elementos semânticos e estéticos (prosódicos, imagéticos e simbólicos).

Esta longa e meticulosa arte poética diz-nos que o poema é um trabalho de arquitetura, desenho e construção. Usamos os adjetivos "longa" e "meticulosa" porque há neste poema, do primeiro ao último verso, termos e expressões que remetem constantemente para o rigor do processo arquitetural e construtivo desta poesia. Entre os primeiros versos, "De papel e saibro/ Se ergue o cabouco/ Do verso (...)" (515), e os últimos, "O poema/ Edifício é" (532), há um percurso demorado e motivado em que intervém um eu que assume responsabilidade tanto do trabalho de estruturação racional e sólida como do que nesta construção tem a ver com sentimentos e vivências: "É chegado/ O tempo/ De levantar/ Colunas/ De cimentar/ Horizontes" (519); "Imprevista força/ Das coisas/ Levanta/ O fungo/ Fértil/ Da infância" (519-520).

Este é um rigor que exige tempo, planeamento e persistência, tal como acontece na construção de um edifício de "pedra" (515), "tijolo" (516) e "cal" (517). Há uma relação de implicação entre tecnologia, técnica e recursos materiais, por um lado, e emoções e afetos, por outro. São inúmeras as palavras e as expressões de áreas semânticas da arquitetura, da engenharia e da construção, sobretudo nas três primeiras secções de "Construir", e frequentes os deíticos de primeira pessoa, como "construo" (516), que colocam este eu no centro de um processo poético que concilia construção e sugestão. $O$ poeta constrói o poema ao mesmo tempo que nos dá as coordenadas da construção de outros poemas, e ao mesmo tempo que, às vezes numa mesma unidade sintática, figura a relação entre o trabalho do construtor (o pedreiro, o carpinteiro...) e o trabalho do poeta: "De perfil o vocábulo/ A parede construo/ Do poema:/ O edifício nasce" (516); "A plaina desbasta/ O guindaste/ Dos nervos. Portas/ Se abrem" (522).

A figuração do poema e do verso como gesto arquitetural não desaparece dos últimos quatro andamentos de "Construir"; mas aqui, porque "É preciso/ Habitar a casa/ O vazio/ De quem/ O trabalho finda/ Um signo/ Espera/ O insondável/ Repouso" (525), os versos tornam-se mais alusivos e evocativos de um intimismo que o poeta quer comunicar com discrição. "Leite e mel/ De justos corpos/ Se unem/ Lentamente" (525) é um bom exemplo desse universo pessoal e íntimo, no caso até no sentido de intimidade erótica e sexual, que aliás é um tópico que atravessa discreta mas intensamente toda a poesia de Liberto Cruz.

Na segunda parte de Três Poemas, escrita em Abril de 2002 e não por acaso intitulada "Evocação", voltam os cenários, os comportamentos e as personagens da guerra que constituíram a matéria de poemas e livros anteriores de Liberto Cruz, e tacitamente o desejo de um mundo mais justo e livre: "Não sei se era/ A postura militar/ O preso torturado/ O soldado sem aprumo/ O receio do capelão/ A 
deserta missa campal/ A loucura do médico/ As minas desfazendo corpos” (538). Não há fronteiras entre a experiência estética que o poema consubstancia, o compromisso ético e a revelação de momentos biográficos, que o leitor tenderá a identificar com o poeta-soldado Liberto Cruz. Toda esta sequência revisita um passado de gestos e memórias que deixam no eu uma sensação de desconforto e indecidibilidade que ele traduz nos versos, que se repetem mais ou menos nos mesmos termos, "Era talvez" e "Não sei se era" (535).

O terceiro poema de "Evocação" retoma e aprofunda este diálogo entre a experiência de vida (de guerra) "Em angolanas terras/ Entre/ Trilhos e longarinas/ Sanzalas e embondeiros" (548), "Ali, na nebulosa do medo" (548), a interioridade mais íntima de quem precisa de procurar o "Alento certo" (549) e encontra força no "(...) rosto/ Da mulher amada" (549), e a reflexão sobre o contexto histórico: "Longe havia longe/ Discursos ditosos/ Promessas e preces/ Soberba e cenário/ Da pátria adormecida./ Mas quem podia insurgir-se?/ Como fechar/ O alçapão do poder?" (549-550).

O poema que compõe a terceira e última parte de Três Poemas tem como objeto os dois referentes que constituem o título (os dois sintagmas surgem justapostos, sem vírgula e sem conjunção coordenativa copulativa, e por isso estão ainda mais unidos sintática e semanticamente): "A Pedra o Corpo". Sóbrio na medida dos versos e às vezes elíptico, mas rico em imagens e sentidos, como é característico da poesia de Liberto Cruz, este texto que encerra a Poesia Reunida (1956 - 2011) fixa-se "Na pedra agora fria/ Do vulcão", onde existe "Quase visível/ Um traço/ De faca interrompida" (553). A partir daqui, intensifica-se a indagação do momento fundador desta pedra e do seu significado telúrico, cósmico e humano: "Punho guerreiro/ Ou santo esboçado/ Na lisura branca/ Da rocha entre folhas/ De água e vento é/ Matéria inominada" (553).

O poema procura delinear, na sua linguagem de mediação, a anatomia desta pedra, que é definida através de metáforas que se alargam em imagens subtis e misteriosas; metáforas que são, por vezes, até certo ponto, sinédoques, já que esta pedra é "lava infatigável" (554), nomeada pelo que nela é luz, calor, fogo: "Feixe luminoso/ Ou tocha apagada/ De refeitas vias/ Se consome" (553-554). Com esta reflexão à volta da "pedra" e, mais à frente, do "corpo" (que também pode ser metáfora de "pedra"), o enunciador quer conhecer o instante e o todo das origens e da perfeição: "Falo de uma pedra/ Agora fria/ De um corpo/ Adiado já./ Matéria vasta/ Do tempo nosso/ Claridade obscura/ Claridade obscura/ Que se inventa/ E seu nome solitário/ Evoca" (555).

O poema persegue a utopia de uma plenitude que o humano possa entender e fruir. No final, todavia, resta apenas a nostalgia desse tempo e desse espaço totais, e a consciência das limitações do Homem na apreensão do Universo e das suas partes: "Mas que sabemos nós/ De uma pedra/ Mas que sabemos nós/ De um corpo/ ainda que ambos perfeitos fossem?" (556).

Trata-se, como se vê, de uma poesia que sempre dialogou com o seu tempo sociocultural, político e literário, e ao mesmo tempo contribuiu, e contribui, para a sua (re)construção. Uma poesia que tem tanto de arte como de comunicação, de sentimento estético como de envolvimento ético. 


\section{OBRAS CITADAS}

Castro de Melo E. M. (1984), Projecto: Poesia. Lisboa: Imprensa Nacional Casa da Moeda.

CoElHo Jacinto do Prado (1987), Unidade e Diversidade em Fernando Pessoa. 9. ${ }^{\mathrm{a}}$ ed. Lisboa, Verbo.

CRUZ Liberto (2007), Gramática Histórica. 2. ${ }^{a}$ ed. revista e aumentada. Prefácios de Haroldo de Campos e João Fernandes. Lisboa: Roma Editora.

CRUZ Liberto (2012), Poesia Reunida (1956 - 2011). Prefácio de Eugénio Lisboa. Lisboa. Coimbra: Palimage.

Eliade Mircea (1997), Tratado de História das Religiões. 3. a ed. Porto: Asa.

GALHOZ Maria Aliete (1998), "Caderno de Encargos, de Liberto Cruz". Colóquio/Letras 147-148 (Jan. 1998): 334-35.

Guimarães Fernando (1989), "Um Tempo de Transição na Poesia de Albano Martins, Cristovam Pavia, Helder Macedo e Liberto Cruz". A Poesia Portuguesa Contemporânea e o Fim da Modernidade. Lisboa: Caminho, p. 63-70.

GuimarÃES Fernando (2012), "Entre a Palavra e a Circunstância”. JL - Jornal de Letras, Artes e Ideias, 27 Jun. 2012, p. 16-17.

LACERDA Daniel (1987), "Jornal de Campanha, de Liberto Cruz". Colóquio/Letras 99 (Set. 1987), p. 89-90.

MACHADO Álvaro Manuel (1996), "Cruz, Liberto da Fonseca Ribeiro da". Dicionário de Literatura Portuguesa. Lisboa: Presença.

MARTelo Rosa Maria (1990), Estrutura e Transposição. Invenção Poética e Reflexão Metapoética na Obra de João Cabral de Melo Neto. Porto: Fundação Eng. António de Almeida.

MARTINHO Fernando J. B (1995), "Cruz (Liberto da Fonseca Ribeiro da)". Biblos - Enciclopédia Verbo das Literaturas de Língua Portuguesa. Vol. 1. Lisboa: Verbo, p. 1407-1409.

MenÉres Maria Alberta; E. M. de Melo e CASTRo (1971). Antologia da Novíssima Poesia Portuguesa. 3. a ed. revista, aumentada e com uma nova Introdução. Lisboa: Morais Editores.

Nunes Benedito (1777), "Distância, de Liberto Cruz”. Colóquio/Letras 38 (Jul. 1777), p. 80-81.

ReIS-SÁ Jorge; Lage Rui (2009), Poemas Portugueses - Antologia da Poesia Portuguesa do Século XIII ao Séc. XXI. Porto: Porto Editora.

SARAIVA António José, e LOPES, Óscar. História da Literatura Portuguesa. 16. ${ }^{\mathrm{a}}$ ed. corrigida e atualizada, Porto: Porto Editora, s.d.

SARTRE Jean-Paul (1940), L'Imaginaire. Psychologie Phénoménologique de l'Imagination. Paris: Gallimard.

SousA João Rui de (1983), “Ciclo, de Liberto Cruz”. Colóquio/Letras 71 (Jan. 1983), p. 90.

WELLEK René; and Austin WARREN (s.d.), "Imagem, metáfora, símbolo, mito". Teoria da Literatura. 5. ${ }^{\mathrm{a}}$ ed. Mem Martins: Publicações Europa-América, p. 229-261. 